\begin{tabular}{c|l|l|l}
$\begin{array}{c}\text { Case Reports in } \\
\text { Oncology }\end{array}$ & $\begin{array}{l}\text { Case Rep Oncol 2011;4:12-15 } \\
\text { DOl: 10.1159/000324041 }\end{array}$ & $\begin{array}{l}\text { Published online: } \\
\text { January 15, 2011 }\end{array}$ & $\begin{array}{l}\text { O 2011 S. Karger AG, Basel } \\
\text { ISSN 1662-6575 } \\
\text { www.karger.com/cro }\end{array}$ \\
\hline
\end{tabular}

\title{
Burned-Out Testicular Tumor: A Case Report
}

\author{
N. Balalaa M. Salman W. Hassen
}

Department of Urology, Tawam Hospital in Affiliation with Johns Hopkins, Al Ain, United Arab Emirates

\section{Key Words}

Burned-out tumor - Germ cell tumor · Testicular tumor

\begin{abstract}
Germ cell tumors constitute the majority of all testicular tumors, which are relatively rare overall and are mainly encountered in young adults and teenagers. The term 'burnedout' germ cell tumor refers to the presence of a metastatic germ cell tumor with histological regression of the primary testicular lesion. Clinical examination of the testes and scrotal sonography is pivotal in the initial diagnosis of such neoplasms. We present a case of a 31-year-old male with a retroperitoneal mass and no palpable lesion on testicular examination.
\end{abstract}

\section{Case Report}

A 31-year-old male was referred to our department with a complaint of intermittent left-sided back pain of 6 months' duration. The pain was dull in nature and radiated to the left groin. He also complained of early satiety, but had not observed any changes in bowel habits or weight loss. He had no abdominal pain.

Physical examination revealed no cervical, axillary or inguinal lymphadenopathy. There was no gynecomastia. Abdominal examination revealed a non-tender, palpable mass in the left upper quadrant extending to below the umbilicus. Scrotal examination revealed a normal right testis. The left testis was atrophic with an area of non-tender induration palpable in the upper pole. However, no discrete mass was detected. Laboratory investigations were within normal ranges, with $\alpha$-fetoprotein $3.2 \mathrm{IU} / \mathrm{l}(0-9$ IU/l), $\beta$ human chorionic gonadotropin hormone $<0.1 \mathrm{IU} / 1(<0.1 \mathrm{IU} / \mathrm{l})$, and a slightly elevated lactate dehydrogenase $291 \mathrm{IU} / \mathrm{l}$ (100-190 IU/l). Scrotal ultrasonography revealed a normal right testis and atrophic left testicle with heterogeneous architecture and scattered microcalcifications (fig. 1). No mass was visualized. Abdominal computed tomography (CT) revealed a left retroperitoneal mass $5-6 \mathrm{~cm}$ in diameter with a cystic and solid component extending from below the left renal vein down to the bifurcation of the aorta (fig. 2).

A left radical orchiectomy was performed. Histopathology showed a well-demarcated nodular scar and atrophy of the seminiferous tubules. There was no evidence of germ cell tumor, and immunostains including PLAP, Oct 4, and CD114 were negative. The patient subsequently underwent a CT-guided retroperitoneal lymph node biopsy which revealed a metastatic germ cell tumor consistent with seminoma. Immunohistochemistry was positive for PLAP, Oct 4, and CD117, and negative for LCA, $\mathrm{CD} 3$, CD15, CD20, and CD 30 (fig. 3a, b). 
Sperm banking was done for the patient followed by three cycles of chemotherapy with bleomycin, etoposide, and cisplatin. Follow-up CT after chemotherapy revealed that the left para-aortic lymphadenopathy had decreased in size to $3.6 \times 1.8 \mathrm{~cm}$. The patient then underwent a retroperitoneal lymph node dissection with preservation of the left kidney. Pathology showed no evidence of malignancy, which was consistent with post-treatment effect.

\section{Discussion}

Extra-gonadal germ cell tumors are rare and predominantly affect young males. They represent $5-10 \%$ of all germ cell tumors. Primary retroperitoneal germ cell tumors are extremely rare and represent only $10 \%$ of all malignant primary retroperitoneal tumors $[1,2]$. Patients with retroperitoneal germ cell tumors usually present late, after their tumors have reached large dimensions. Presenting symptoms and signs include a palpable mass, with or without pain, weight loss, constipation, hip and back pain, dyspnea, leg edema, fever, varicocele, and urinary retention $[3,4]$.

The 'burned-out' phenomenon in germ cell tumors refers to a germ cell tumor in extra-gonadal tissues with spontaneous regression of an intra-gonadal tumor. Extragonadal germ cell tumors are usually found in the retroperitoneal, supraclavicular, cervical, and axillary lymph nodes and occasionally in the lung and liver. There are two theories to explain this phenomenon. The first is spontaneous regression of a primary germ cell tumor after metastasis of the germ cell tumor. The mechanism of this regression is yet to be elucidated. Possible explanations are an immune response or ischemia caused by the neoplasm outgrowing its blood supply due to its high metabolic rate.

A second hypothesis is the de-novo development of a primary germ cell tumor in extra-gonadal tissues [5]. Patients with extra-gonadal germ cell tumors with the burnedout phenomenon usually complain of many vague symptoms, such as flank pain, abdominal mass, night sweating, or scrotal pain, and occasionally reveal an elevated testicular tumor marker. In our case, the patient complained of left-sided back pain without elevation of tumor markers [5]. Histological features that are helpful in establishing a diagnosis of a regressed testicular germ cell tumor include, apart from the scar formation, intratubular calcifications, lymphoplasmacytic infiltrate, hemosiderincontaining macrophages, and testicular atrophy [6].

Burned-out tumors may cause some confusion in the diagnosis, because secondary tumors can often be mistaken for primary tumors. Careful evaluation of the testis is crucial for identifying the primary lesion site; all abnormalities shown on clinical or sonographic scrotal examination call for orchiectomy [7].

High-resolution sonography of the scrotum with linear high-frequency transducers allows the detection of small, highly echogenic foci, hypoechoic zones, microlithiasis or microcalcifications as in our case $[2,8,9]$. Primary extra-gonadal germ cell tumors are more aggressive than primary testicular cancer and are more resistant to chemotherapeutic agents. Seminomatous extra-gonadal germ cell tumors are sensitive to chemotherapy and are treated similarly to primary seminomas with three or four cycles of cisplatin, etoposide, and bleomycin. On the other hand, non-seminomatous extragonadal germ cell tumors are frequently chemoresistant with 5 year survival rates of $65 \%$ [10]. 


\begin{tabular}{c|l|l|l}
$\begin{array}{c}\text { Case Reports in } \\
\text { Oncology }\end{array}$ & $\begin{array}{l}\text { Case Rep Oncol 2011;4:12-15 } \\
\text { DOI: 10.1159/000324041 }\end{array}$ & $\begin{array}{l}\text { Published online: } \\
\text { January 15, 2011 }\end{array}$ & $\begin{array}{l}\text { O 2011 S. Karger AG, Basel } \\
\text { ISSN 1662-6575 } \\
\text { www.karger.com/cro }\end{array}$ \\
\hline
\end{tabular}

\section{Conclusion}

It is mandatory to perform a testicular ultrasound, despite a (normal or suspicious) physical examination of the scrotum in the work-up of male patients presenting with a retroperitoneal mass. Metastatic disease secondary to burned-out lesion has the same prognosis as a primary testicular malignancy; therefore, it is important that it is recognized.

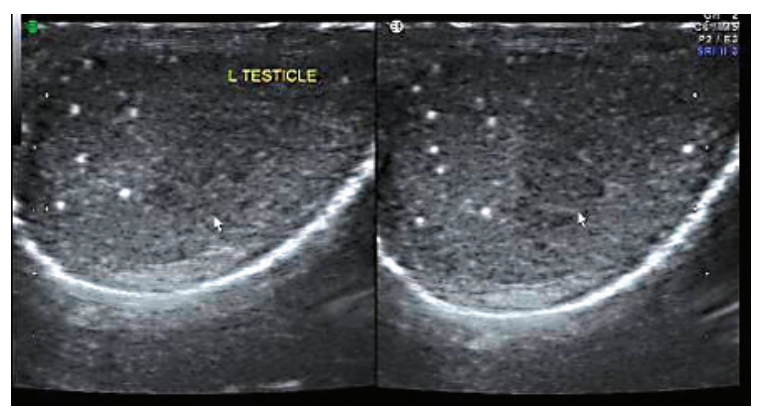

Fig. 1. Ultrasound of the left testis showing scattered microcalcifications.

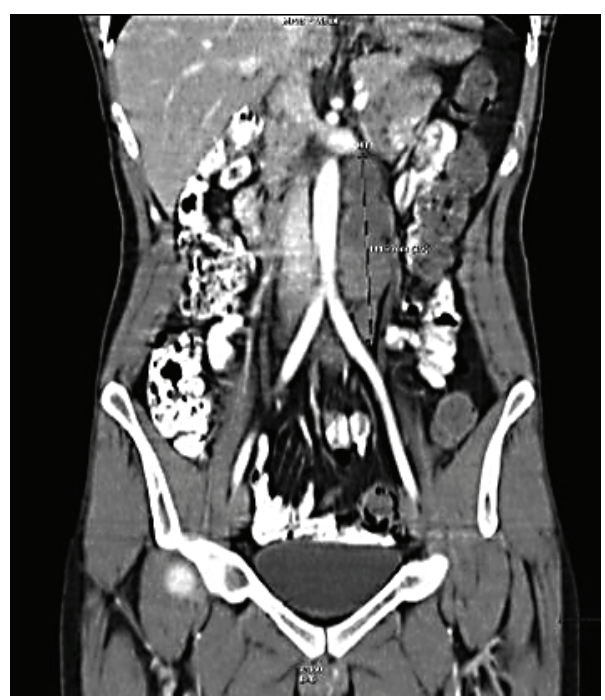

Fig. 2. Abdominal CT scan showing a retroperitoneal mass on the left side of the aorta compressing the left renal vein. 


\begin{tabular}{c|l|l|l}
$\begin{array}{c}\text { Case Reports in } \\
\text { Olloloyy }\end{array}$ & $\begin{array}{l}\text { Case Rep Oncol 2011;4:12-15 } \\
\text { DOI: } 10.1159 / 000324041\end{array}$ & $\begin{array}{l}\text { Published online: } \\
\text { January 15, 2011 }\end{array}$ & $\begin{array}{l}\text { ISSN 1662-6575 } \\
\text { www.karger.com/cro }\end{array}$ \\
\hline
\end{tabular}
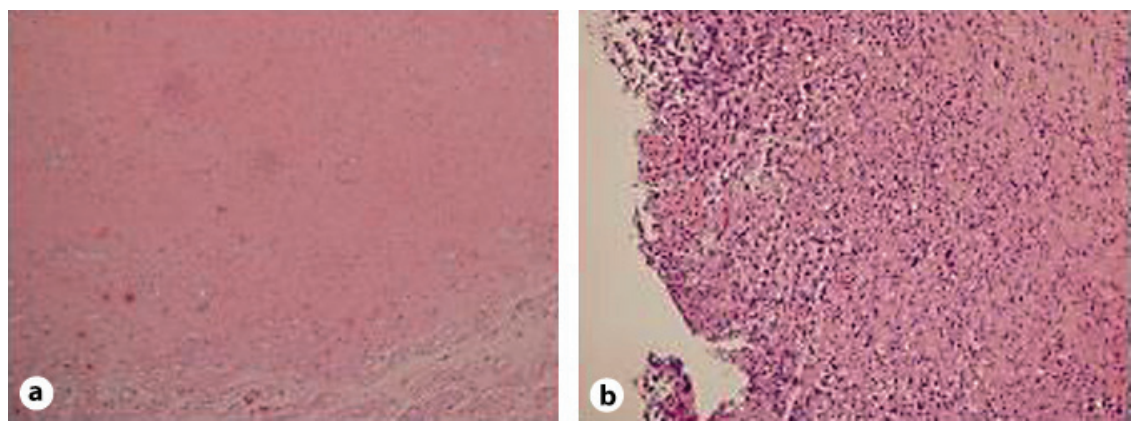

Fig. 3. a Histopathology of the left testis showing a well-demarcated central scar lesion with hyalinized seminiferous tubules (HE stain). b Histopathology of the left retroperitoneal mass showing seminomatous germ cells infiltrating a retroperitoneal lymph nodes (HE stain, $\times 10$ ).

\section{References}

$\checkmark 1$ Woodward PJ, Sohaye R, O’Donoghue MJ, Green DE: Tumors and tumor like lesions of the testis: radiologicpathologic correlation. Radiographics 2002;22:189-216.

2 Choyke PL, Hayes WS, Sesterhenn IA: Primary extragonadal germ cell tumors of the retroperitoneum: differentiation of primary and secondary tumors. Radiographics 1993;13:1365-1375.

-3 Buskirk SJ, Evans RG, Farrow GM, et al: Primary retroperitoneal seminoma. Cancer 1982;49:1934-1936.

$\checkmark 4$ Abel MR, Fayos JV, Lampe L: Retroperitoneal germinomas (seminomas) without evidence of testicular involvement. Cancer 1965;18:273-290.

5 Ha HK, Jung SG, Park SW, Lee W, Lee SD, Chung MK: Retroperitoneal seminoma with the 'burned out' phenomenon in the testis. Korean J Urol 2009;50:516-519.

6 Bar W, Hedinger C: Comparison of histologic types of primary testicular germ cell tumors with their metastases: consequences for the WHO and the British nomenclatures? Virchows Arch A Pathol Anat Histol 1976;370:41-54

7 Tasu JP, Faye N, Eschwege P, Rocher L, Blery M: Imaging of burned-out testis tumor: five new cases and review of the literature. J Ultrasound Med 2003;22:515-521.

8 Kebapci M, Can C, Isiksoy S, Aslan O, Oner U: Burned-out tumor of the testis presenting as supraclavicular lymphadenopathy. Eur Radiol 2002;12:371-373.

\9an Dijk R, Hitge-Boetes C, Debruyne FM, Rosensbusch G: Sonographic detection of a non-palpable regressed germ cell tumor in an atrophic testis. J Clin Ultrasound 1989;17:594-597.

10 Israel A, Bosl GJ, Golbey RB, Whitmore W Jr, Martini N: The results of chemotherapy for extra-gonadal germcell tumors in the cisplatin era: the Memorial Sloan-Kettering Cancer Center experience (1975 to 1982). J Clin Oncol 1985;3:1073-1078. 